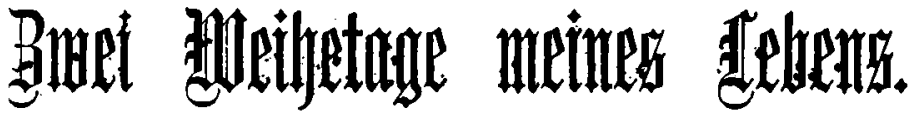

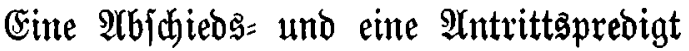

von

\section{Wilhelm Bahnien,}

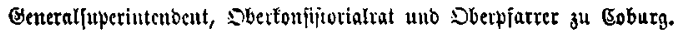

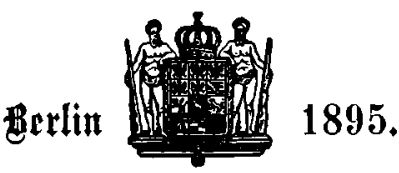

Der lag von hermann Peters.

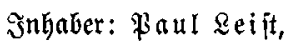

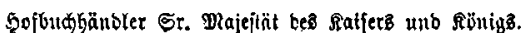


